\title{
Assessment of the usefulness of silicone plaster application on a postoperative scar in women after mastectomy because of breast malignancy: a preliminary report
}

\section{Ocena przydatności zastosowania plastrów silikonowych na bliznę pooperacyjna u kobiet po odjęciu piersi z powodu nowotworu złośliwego-doniesienie wstępne}

\author{
Anna Lipińska1,2, Małgorzata Terek-Derszniak³, Magdalena Lipińska-Stańczak ${ }^{1}$, Łukasz Żurawski , \\ Anna Żurawska4, Tomasz Ridan ${ }^{5}$ Paweł Macek ${ }^{3,4,6}$, Zbigniew Śliwiński1,7
}

IInstitute of Physiotherapy, Faculty of Medicine and Health Sciences, Jan Kochanowski University, Kielce, Poland Head of the Institute: Prof. JKU Zbigniew Śliwiński MD, PhD

${ }^{2}$ Department of Rehabilitation, Independent Public Health Care, MSWiA, Kielce, Poland

Head of the Department: Anna Lipińska MD, PhD

${ }^{3}$ Department of Rehabilitation, Holycross Cancer Center, Kielce, Poland

Head of the Department: Anna Opuchlik PhD

${ }^{4}$ School of Economics, Low and Medical Sciences, Kielce, Poland

Head of the School: Grzegorz Gałuszka PhD

${ }^{5}$ Department of Physiotherapy, Faculty of Kinesiotherapy, University of Physical Education, Krakow, Poland

Head of the Department: Prof. AWF Marek Pieniążek MD, PhD

${ }^{6}$ Department of Epidemiology and Fight against Cancer, Holycross Cancer Center, Kielce, Poland

Head of the Department: Paweł Macek PhD

${ }^{7}$ Multispecialist Independent Public Health Care Centre, Stationary Rehabilitation Centre, Physiotherapy Centre, Zgorzelec, Poland

Head of the Centre: Prof. JKU Zbigniew Śliwiński MD, PhD

Key words: breast cancer, keloids, scars, silicon plaster.

Słowa kluczowe: rak piersi, bliznowce, blizny, plaster silikonowy.

\begin{abstract}
Introduction: In the natural process of wound healing a scar is formed, which by its build, colour, and function does not resemble healthy tissue. This concerns not only the appearance of the outer integument, but above all, the deeper layers, which are also subject to the process of scarring. In some cases, a disorder of the decomposition and synthesis of collagen takes place and then hypertrophied scars and colloids are formed. Therefore, in physiotherapeutic practice, a scar should be seen in the three-dimensional aspect. Oncology patients can have so-called silicone dressings applied in the healing process of hypertrophied scars and colloids. The therapy using plasters with silicone gel is safe and non-invasive.

Aim of the research: To assess the impact of silicone plasters on postoperative scars in the rehabilitation of women after mastectomy.

Material and methods: The study, in which women after mastectomy took part, was performed in the Holycross Cancer Centre in Kielce. The assessment of a postoperative scar was based on the Patient and Observer Scar Assessment Scale (POSAS). Results and conclusions: Silicone dressings applied on a postoperative scar influenced its flexibility, colour, and size. The achieved results are satisfactory, and the applied method is effective and promising. However, the methods used to assess the scar, which are commonly recommended but not quite objective, raise some reservations and doubts among the authors.
\end{abstract}

\section{Streszczenie}

Wprowadzenie: W procesie naturalnego gojenia ran powstaje blizna, która budową, barwą i funkcją nie przypomina zdrowej tkanki. Dotyczy to nie tylko wyglądu powłoki zewnętrznej, lecz przede wszystkim warstw głębiej położonych, które również podlegają procesowi bliznowacenia. W niektórych przypadkach dochodzi do zaburzenia rozkładu oraz syntezy kolagenu i wówczas tworzą się blizny przerostowe oraz keloidy. Dlatego też w praktyce fizjoterapeutycznej blizna powinna być postrzegana w sposób trójwymiarowy. Pacjentom onkologicznym w procesie leczenia blizn przerostowych i keloidów można zaaplikować tzw. opatrunki silikonowe. Terapia za pomocą plastrów z żelem silikonowym jest bezpieczna i nieinwazyjna. Cel pracy: Ocena wpływu plastrów silikonowych na bliznę pooperacyjną w rehabilitacji kobiet po mastektomii. 
Materiał i metody: Badanie, w którym wzięły udział kobiety po mastektomii, przeprowadzono w Świętokrzyskim Centrum Onkologii w Kielcach. Ocenę blizny pooperacyjnej ustalono na podstawie Patient and Observer Scar Assessment Scale (POSAS). Wyniki i wnioski: Opatrunki silikonowe stosowane na bliznę pooperacyjną wpłynęły na jej elastyczność, kolor oraz rozmiar. Osiągnięte wyniki są zadowalające, a opisana metoda jest skuteczna i obiecująca. Wśród autorów pracy pewne zastrzeżenia i wątpliwości budzą jednak zastosowane metody oceny blizny, które są powszechnie zalecane, ale nie są dość obiektywne.

\section{Introduction}

Wound healing is a complex process, which may result in the restoration of anatomic continuity and functionality of damaged tissue $[1,2]$. It begins at the time of the wound creation and can last for many months or even years. This process consists of a sequence of successive steps:

The inflammatory phase (up to 7 days after the injury), which is divided into haemostasis and the inflammatory state. During haemostasis, platelets seal the damaged blood vessels, forming a plug. The inflammatory state is accompanied by migration of phagocytic cells (macrophages, granulocytes, monocytes), which form a line of defence against infections and produce various compounds such as: fibroblast growth factor (FGF), epidermal growth factor (EGF), transforming growth factor (TGF), and interleukin-1 (IL-1), leading to the next phase.

The phase of proliferation (3-4 weeks after the injury) involves an exchange of cutaneous tissue, and sometimes, in the case of deeper wounds, also subcutaneous tissue, as well as closing the margins of the wound. The primary cells for further regeneration are: fibroblasts, which secrete collagen, proteoglycans, and fibres of the intercellular substance, keratinocytes responsible for the process of angiogenesis, and keratinocytes, which are responsible for epithelialisation.

The phase of reconstruction and modelling (up to 2 years after the injury) is a phase when an immature scar is formed, which includes a disorganised system of fine collagen fibres that is gradually replaced by thicker fibres arranged in the orientation corresponding to the tension of the skin [1-4].

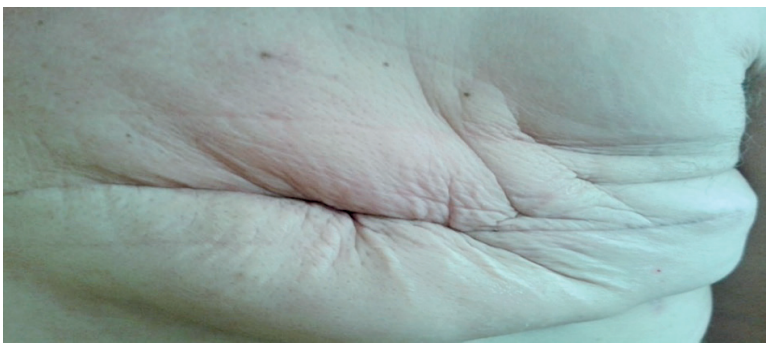

Figure 1. A postoperative scar after the removal of a breast
A wound healing process sometimes differs from the above scheme. The phase of modelling the scar may be affected by such factors as:

- individual tendency to an excessive healing reaction, more common in the black race,

- delayed scarring, which can be caused by, among others: steroids, cytostatics, and deficiencies in protein and vitamins $\mathrm{A}$ and $\mathrm{E}$,

- diabetes and rheumatic diseases, which can interfere with the healing process,

- incorrect sutures,

- peripheral vascular diseases occurring with impaired tissue perfusion.

- wound infections,

- the patient's age $[2,4-6]$.

The scar is different from the healthy skin in, among others: smoothness of the epidermis, the absence of fine grooves on the dermal-epidermal border, and the absence of skin appendages and elastic fibres, which reduces its resistance to stretching [2, 3, 6]. Usually, the process of scar healing does not require special therapeutic management, but in some cases, keloids and hypertrophied scars are created. A pathological process of scarring is for the patient a significant problem because it causes functional, aesthetic, and psychological disorders $[7,8]$.

In patients after mastectomy, a frequent complication is extensive fibrosis with contractures of soft tissue. In the process of healing, the scar may adhere to tendons, ligaments, or a joint capsule, and then it may contribute to contractures and deformations (Figure 1).

These changes, together with skin scarring, retard or stop the process of lymphatic vessel regeneration, leading to the failure of lymph circulation and the formation of secondary lymphoedema on the operated side. The impaired lymph flow increases the number of trophic changes of the skin around the scar (bruising, flaking, cooling, cracking, ulceration); it can also cause skin infections, which will secondarily intensify the symptoms. Regeneration of lymphatic vessels is associated with the patients'genetic predispositions, and therefore the changes described above have different severity [9].

Treatment of hypertrophic scars and keloids is a serious therapeutic problem. Various methods are used in the process of reducing these complications

Table 1. Age of the respondents

\begin{tabular}{|lcccc|}
\hline Variable & Mean & SD & Min. & Max. \\
\hline Age & 60.18 & 7.69 & 48.00 & 76.00 \\
\hline
\end{tabular}


Table 2. Patient and Observer Scar Assessment Scale [13]

\begin{tabular}{|c|c|c|c|c|c|c|c|c|c|c|c|}
\hline \multicolumn{12}{|c|}{ Observer component } \\
\hline $\begin{array}{l}\text { Normal skin } \\
\text { imaginable }\end{array}$ & 1 & 2 & 3 & 4 & 5 & 6 & 7 & 8 & 9 & 10 & Worst scar \\
\hline \multicolumn{12}{|l|}{ Vascularisation } \\
\hline \multirow[t]{3}{*}{ Pigmentation } & & & & & & & & & & & Hypo \\
\hline & & & & & & & & & & & Mix \\
\hline & & & & & & & & & & & Hyper \\
\hline \multicolumn{12}{|l|}{ Thickness } \\
\hline \multicolumn{12}{|l|}{ Relief } \\
\hline \multicolumn{12}{|l|}{ Pliability } \\
\hline \multicolumn{12}{|c|}{ Patient component } \\
\hline No, no complaints & 1 & 2 & 3 & 4 & 5 & 6 & 7 & 8 & 9 & 10 & Yes, worst imaginable \\
\hline \multicolumn{12}{|l|}{ Is the scar painful? } \\
\hline \multicolumn{12}{|l|}{ Is the scar itching? } \\
\hline No, as normal skin & 1 & 2 & 3 & 4 & 5 & 6 & 7 & 8 & 9 & 10 & Yes, very different \\
\hline \multicolumn{12}{|l|}{$\begin{array}{l}\text { Is the colour of the } \\
\text { scar different? }\end{array}$} \\
\hline \multicolumn{12}{|l|}{ Is the scar more stiff? } \\
\hline \multicolumn{12}{|l|}{$\begin{array}{l}\text { Is the thickness of } \\
\text { the scar different? }\end{array}$} \\
\hline Is the scar irregular? & & & & & & & & & & & \\
\hline
\end{tabular}

i.e. surgical, pharmacological, and physical. Recently, the pharmaceutical industry has opened new possibilities for the treatment of hypertrophic scars and keloids, by introducing silicone dressings [10]. The use of silicone plasters is recommended as a safe, noninvasive, simple, and effective prophylactic method [11]. Their systematic use greatly improves the elasticity of scars, compared with scars treated differently. Most researchers studying the impact of silicone on the scar believe that silicone dressings reduce the activity of capillary vessels, and congestion and production of fibroblasts and collagen, causing flattening of the scar. Randomised studies have shown that the use of silicone dressings is effective in the improvement of the colour, size, and hardness of scars [12]. They are also used for prophylactic reasons after a surgical excision of keloids and hypertrophic scars [7].

\section{Aim of the research}

The main aim of the study is to evaluate the influence of silicone plasters on a postoperative scar in rehabilitation of women after mastectomy.

\section{Material and methods}

The study was conducted in Holycross Cancer Centre in Kielce. It was attended by 22 women who, due to breast cancer, had a breast and lymph nodes of the axillary cavity removed. The youngest patient was 48 years old, and the oldest was 76 (Table 1).

The study group was selected by appropriate criteria including and excluding patients from the process of the discussed therapy.

Inclusion criteria: surgery of one-sided, modified, radical mastectomy, a completed process of scar epidermisation, the lack of induction chemotherapy, the lack of treatment with steroids, adjuvant chemotherapy not started, radiotherapy not started, minimum 4 weeks after the surgery.

Exclusion criteria: every other than a modified, radical amputation, surgery in the area of breast, or two-sided mastectomy, not completed process of scar epidermisation, application of induction chemotherapy, adjuvant chemotherapy started, treatment with steroids started, radiotherapy started, fewer than 4 weeks after the surgery.

The patient could also be excluded from the study because of: aware, personal resignation from participation in the study, the doctor's decision to withdraw the patient from the study, occurrence of allergic reactions after the applied therapy, occurrence of other health complications, deterioration of health as a result of treating the basic disease or other diseases.

In the study group, scar treatment was carried out with the use of a silicone plaster. The change of a nonsterile silicone dressing was done once a week. The 
silicone product was maintained on the scar for $24 \mathrm{~h}$ with a 1-hour break for hygienic operations.

The evaluation of the postoperative scar was based on the Patient and Observer Scar Assessment Scale (POSAS) (Table 2) [13]. The Patient and Observer Scar Assessment Scale consists of two elements. One element is completed by the observer, and the other is assessed by the patient. The patient assesses the thickness, flexibility, colour, pain, and itching, and the observer assesses vascularisation, pigmentation, thickness, and mobility. Each element is rated on a scale of 0 to 10 where 10 is the worst imaginable scar.

\section{Statistical analysis}

Statistical analysis was performed with the use of Microsoft Office 2010 and Statistica 12 software Advanced Package with Medical Kit, with the license of Holycross Cancer Centre in Kielce, license number AXAP504G476028FACN1-8. The authors calculated: 1) basic statistics: arithmetic mean, standard deviation, and extreme values; 2 ) the efficacy of the therapy before and after its completion on the basis of the observer and patient components was checked with the use of Wilcoxon's matched-pairs test; 3) the dependence of the value of improvement on the number of visits was verified by using the nonparametric Spearman correlation.

The level of statistical significance was $p<0.05$.

\section{Results}

Analysis of the differences of the studied parameters before and after the treatment on the basis of the observer component showed a statistical significance $(p<0.05)$ in terms of all the tested characteristics. The average value for the parameter 'normal skin' before the therapy was 2.50 and after the therapy 1.59; for the parameter 'vascularisation' before starting the thera- py, the average value was 2.45 and after the therapy 1.55; for the examined variable 'pigmentation' before starting the therapy, the average value was 2.82 and after the therapy 1.77; for the characteristics 'thickness', the average value before the therapy was 3.45 and after the therapy 2.59; for the parameter 'relief' before the therapy was 3.00, and after the therapy 1.91; and for the parameter 'pliability' before the therapy, the average value was 4.14 , and after the therapy 2.82 (Table 3 ).

In the process of analysing the differences of the studied parameters before and after completing the therapy on the basis of the patient component, there was statistically significant $(p<0.05)$ improvement in all the studied variables. The mean value of the characteristic 'Is the scar painful?' before the test was 1.91, and after its completion 1.23; for the parameter 'Is the scar itching?' before the therapy was 1.27 and after the therapy 1.09; for the parameter 'Is the colour of the scar different?' before the therapy the average value was 3.23, and after its completing 1.86; for the parameter 'Is the scar more stiff?', the average values before the therapy were 3.71, and after the therapy 2.05; for the studied variable 'Is the thickness of the scar different?', before the therapy the mean value was 3.27, and after the treatment 1.95; for the parameter 'Is the scar irregular?', in the beginning it was 4.27 , and at the end of the research process 2.45 (Table 4 ).

Out of 22 patients $(n=100 \%)$ in two therapy sessions $13.64 \%(n=3)$ of patients participated, in three $22.73 \%(n=8)$, in four $13.64 \%(n=3)$, in five $45.45 \%$ $(n=10)$, and in six $4.55 \%(n=1)$ of patients (Table 5$)$.

Based on the obtained results, an improvement in all the examined variables was found. The most significant differences in the improvement was observed in the case of the following variables:

- thickness;

- is the scar more stiff?

- is the thickness of the scar different?

Table 3. Differences of the studied parameters before and after the therapy based on the observer component

\begin{tabular}{|c|c|c|c|c|c|c|c|}
\hline Variable & & $N$ valid & Mean & SD & Min. & Max. & $P$-value \\
\hline \multirow[t]{2}{*}{ Normal skin } & Before & 22 & 2.50 & 0.86 & 1.00 & 4.00 & \multirow[t]{2}{*}{$<0.05$} \\
\hline & After & 22 & 1.59 & 0.67 & 1.00 & 3.00 & \\
\hline \multirow[t]{2}{*}{ Vascularisation } & Before & 22 & 2.45 & 0.80 & 1.00 & 4.00 & \multirow[t]{2}{*}{$<0.05$} \\
\hline & After & 22 & 1.55 & 0.60 & 1.00 & 3.00 & \\
\hline \multirow[t]{2}{*}{ Pigmentation } & Before & 22 & 2.82 & 1.01 & 1.00 & 5.00 & \multirow[t]{2}{*}{$<0.05$} \\
\hline & After & 22 & 1.77 & 0.87 & 1.00 & 4.00 & \\
\hline \multirow[t]{2}{*}{ Thickness } & Before & 22 & 3.45 & 1.84 & 1.00 & 10.00 & \multirow[t]{2}{*}{$<0.05$} \\
\hline & After & 22 & 2.59 & 1.94 & 1.00 & 7.00 & \\
\hline \multirow[t]{2}{*}{ Relief } & Before & 22 & 3.00 & 1.15 & 1.00 & 5.00 & \multirow[t]{2}{*}{$<0.05$} \\
\hline & After & 22 & 1.91 & 0.81 & 1.00 & 4.00 & \\
\hline \multirow[t]{2}{*}{ Pliability } & Before & 22 & 4.14 & 2.25 & 1.00 & 9.00 & \multirow[t]{2}{*}{$<0.05$} \\
\hline & After & 22 & 2.82 & 1.94 & 1.00 & 9.00 & \\
\hline
\end{tabular}


Table 4. Differences of the studied parameters before and after completing the therapy based on the patient component

\begin{tabular}{|c|c|c|c|c|c|c|c|}
\hline Variable & & $N$ valid & Mean & SD & Min. & Max. & $P$-value \\
\hline \multirow[t]{2}{*}{ Is the scar painful? } & Before & 22 & 1.91 & 1.11 & 1.00 & 4.00 & \multirow[t]{2}{*}{$<0.05$} \\
\hline & After & 22 & 1.23 & 0.53 & 1.00 & 3.00 & \\
\hline \multirow[t]{2}{*}{ Is the scar itching? } & Before & 22 & 1.27 & 0.55 & 1.00 & 3.00 & \multirow[t]{2}{*}{$<0.05$} \\
\hline & After & 22 & 1.09 & 0.29 & 1.00 & 2.00 & \\
\hline \multirow[t]{2}{*}{ Is the colour of the scar different? } & Before & 22 & 3.23 & 1.19 & 1.00 & 6.00 & \multirow[t]{2}{*}{$<0.05$} \\
\hline & After & 22 & 1.86 & 0.64 & 1.00 & 3.00 & \\
\hline \multirow[t]{2}{*}{ Is the scar more stiff? } & Before & 22 & 3.77 & 1.54 & 2.00 & 9.00 & \multirow[t]{2}{*}{$<0.05$} \\
\hline & After & 22 & 2.05 & 1.13 & 1.00 & 6.00 & \\
\hline \multirow{2}{*}{$\begin{array}{l}\text { Is the thickness of the scar } \\
\text { different? }\end{array}$} & Before & 22 & 3.27 & 1.64 & 2.00 & 9.00 & \multirow[t]{2}{*}{$<0.05$} \\
\hline & After & 22 & 1.95 & 1.33 & 1.00 & 7.00 & \\
\hline \multirow[t]{2}{*}{ Is the scar irregular? } & Before & 22 & 4.27 & 2.73 & 1.00 & 10.00 & \multirow[t]{2}{*}{$<0.05$} \\
\hline & After & 22 & 2.45 & 1.37 & 1.00 & 6.00 & \\
\hline
\end{tabular}

Table 5. Numerical and percentage characteristics of the patients according to the number of visits

\begin{tabular}{|lcccc|}
\hline $\begin{array}{l}\text { Number } \\
\text { of visits }\end{array}$ & $\begin{array}{c}\text { Number } \\
\text { of patients }\end{array}$ & $\begin{array}{c}\text { Cumulated number } \\
\text { of patients }\end{array}$ & $\begin{array}{c}\text { Percentage } \\
\text { of patients }\end{array}$ & $\begin{array}{c}\text { Cumulated percentage } \\
\text { of patients }\end{array}$ \\
2 & 3 & 3 & 13.64 & 13.64 \\
3 & 5 & 8 & 22.73 & 36.36 \\
5 & 3 & 11 & 13.64 & 50.00 \\
6 & 10 & 21 & 45.45 & 95.45 \\
\hline
\end{tabular}

Table 6. Improvement of the appearance of scars resulting from the conducted therapy - statistical description

\begin{tabular}{|lllllll|}
\hline Variable & $N$ valid & Mean & SD & Min. & Max. & $\begin{array}{c}\text { Statistical } \\
\text { description }\end{array}$ \\
Normal skin & 22 & 0.91 & 0.43 & 0 & 2 & 190 \\
Vascularisation & 22 & 0.91 & 0.43 & 0 & 2 & 190 \\
Pigmentation & 22 & 1.05 & 0.58 & 0 & 2 & 190 \\
Thickness & 22 & 1.45 & 0.74 & 1 & 3 & 253 \\
Relief & 22 & 1.09 & 0.53 & 0 & 2 & 210 \\
Pliability & 22 & 1.32 & 1.49 & -3 & 4 & 174 \\
Is the scar painful? & 22 & 0.68 & 0.84 & 0 & 3 & 66 \\
Is the scar itching? & 22 & 0.18 & 0.39 & 0 & 1 & 10 \\
Is the colour of the scar different? & 22 & 1.36 & 1.05 & 0 & 5 & 210 \\
Is the scar more stiff? & 22 & 1.73 & 0.88 & 1 & 3 & 253 \\
Is the thickness of the scar different? & 22 & 1.32 & 0.65 & 1 & 3 & 253 \\
Is the scar irregular? & 22 & 1.82 & 1.56 & 0 & 6 & 190 \\
\hline
\end{tabular}


Table 7. Dependence of the improvement of scars on the number of visits

\begin{tabular}{|lcc|}
\hline Variable & $\rho$ Spearman & $P$-value \\
Normal skin & -0.20 & 0.38 \\
Vascularisation & -0.20 & 0.38 \\
Pigmentation & -0.01 & 0.97 \\
Thickness & -0.04 & 0.87 \\
Relief & -0.23 & 0.31 \\
Pliability & -0.07 & 0.76 \\
Is the scar painful? & 0.38 & 0.08 \\
Is the scar itching? & 0.39 & 0.07 \\
Is the colour of the scar & -0.26 & 0.25 \\
different? & & \\
Is the scar more stiff? & 0.07 & 0.77 \\
Is the thickness of the & 0.04 & 0.86 \\
scar different? & -0.20 & 0.38 \\
\hline Is the scar irregular? & & \\
\hline
\end{tabular}

The conclusion that the three factors are related to the biggest improvement is based on the value of test statistics of Wilcoxon's paired test (signed-rank). The ranking of the values of test statistics indicates the ranking of the factors regarding the improvement (Table 6).

In order to check whether there is a statisticwal relationship between the improvement of the state of the scar and the number of visits, a non-parametric Spearman rank correlation test was carried out. Based on the obtained results, the lack of relationship between the improvement of the state of the scar and the number of visits was found (Table 7).

\section{Discussion}

Local and general factors influence the process of wound healing. The general factors are: bad nutrition, protein deficiency, vitamins $\mathrm{A}$ and $\mathrm{E}$, medicine such as steroids, cytostatic drugs, circulation disorders, advanced age, cancer, and diabetes. Local factors are: bad vascularisation, infections, medicine, radiotherapy, and bad surgical technique. All of these factors influence the formation of a scar. Factors that were considered in our own research are age and oncological treatment (chemotherapy and radiotherapy).

Due to the limited therapeutic efficacy of other methods for the treatment of hypertrophic scars and keloids, silicone dressings are increasingly used. Silicone preparations applied to the skin cause:

1 . Reduction of the activity of capillary vessels.

2. Reduction of hyperaemia.

3. Reduction of fibroblasts and collagen production.

Notable effects for the patient are:

1. Smoothing and flattening of the scar.
2. Reduction of the redness of the scar.

3 . Reduction of the size and hardness of the scar.

4. Increase in the flexibility of the scar [7, 9].

Silicone dressings, because of so many unique advantageous features, should be used in the prophylaxis first, especially in people prone to scarring. It is believed that early treatment of a hypertrophic scar or keloid is of great importance for the effectiveness of the therapy [11]. Silicone plasters used on a scar protect it from external factors and from the loss of moisture, thus, they cause an increase in the amount of water in the corneal layer of the skin and limitation of an excessive loss of water in the processes of physiological evaporation [14]. The study also demonstrates that, due to the oxygen permeability, the skin as well as the scar under the silicone plaster 'breathes' in a natural way. Application of silicone preparations does not cause the feeling of astringing and discomfort of wearing them, and after removing silicone plasters from the skin, they do not lose their adhesive properties, thanks to which they can be re-used [15-18].

The own study shows that the therapy applied in the form of silicone dressings has a satisfactory effect on the appearance of the scar, i.e. on: vascularisation, pigmentation, thickness, relief and deformation. An essential improvement $(p<0.05)$ of all the parameters tested on the basis of the observer component, assessed before and after completing the therapy, was stated. According to the patient's assessment, the scar in terms of its thickness, flexibility, colour, pain, and itching also changed favourably under the influence of the applied silicone plasters. Analysis of the results of differences of the parameters studied before and after the therapy on the basis of the patient component, showed statistically significant $(p<0.05)$ improvement in all the studied variables.

Similar conclusions were observed by Macek et al. [19], who used non-sterile silicone dressings in a patient after mastectomy and removal of lymph nodes in the axillary fossa because of breast cancer.

Patients qualified to the study participated in it with different commitment. The reasons for not finishing the project by some patients were: allergy or redness around the scar, starting radiotherapy or chemotherapy, malaise, and treatment fatigue. Despite these drawbacks, a statistically significant correlation between the quality of the improvement and the number of treatment sessions was not found.

The research results achieved through statistical analysis are satisfactory and they demonstrate that the applied method is effective and promising for the treatment of scars. However, the methods of scar assessment, which are commonly recommended but not objective enough, raise some objections and doubts among the authors of the study. The presented work is an initial announcement; therefore, continuation of the research should be expected, despite many difficulties encountered by the authors. Due to 
the low number of people participating in the experiment, the test results are not binding but give hope that the complications after treatment of malignant breast cancer can be alleviated.

Despite many known methods for scar treatment, there are still few effective preparations applied in non-invasive therapy, and none is fully effective. Some of them do not have any proven therapeutic efficacy, or there is lack of current research on this matter. Due to a limited number of scientific reports on the use and impact of silicone plasters on the scars in patients treated for malignant tumours, it is necessary to increase efforts in order to study the topic thoroughly.

\section{Conclusions}

Silicone plasters improve the appearance of scars. Silicone preparations used in the study favourably influence all the examined variables. Silicone plasters should be used first in prevention. It is necessary to start work to develop an objective questionnaire evaluating scars.

\section{Conflict of interest}

The authors declare no conflict of interest.

\section{References}

1. Kane D. Chronic Wound Care: A Clinical Source Book for Healthcare Professionals. $2^{\text {nd }}$ ed. Wayne, PA: Health Management Publications 1997; 336-43.

2. Martini MC, Placek W (eds Polish edition). Kosmetologia i farmakologia skóry. PZWL, Warsaw 2006; 280-90.

3. Osiak K. Przerostowe blizny, bliznowce i przykurcze bliznowate. Postep Nauk Med 2005; 18 (2/3).

4. Fornalski J. Gojenie się ran z bliznowaceniem - metody. Nowa Medycyna 2006; 4: 66-70.

5. Dąbrowiecki S. Fizjologia i patofizjologia procesu gojenia ran. Pol Med Paliat 2003; 2: 283.

6. Mackiewicz-Wysocka M, Dańczak-Pazdrowska A, Żaba R. Patogeneza oraz wybrane metody leczenia blizn przerosłych i bliznowców. Przew Lek 2007; 5: 79-86.

7. Zieliński T, Witmanowski H, Lewandowicz E, Łuczkowska M, Kruk-Jeromin J. Blizny przerostowe i keloidy. Część II. Zapobieganie i leczenie. Postep Derm Alergol 2008; 25: 116-24.

8. Roguś-Skorupska D. Bliznowce - epidemiologia, etiopatogeneza i leczenie. Nowa Medycyna 2002; 9: 7-11.

9. Hansdorfer-Korzon R, Burakowska A. Zmiany w obrębie skóry u pacjentek po mastektomii z powodu raka sutka. Forum Medycyny Rodzinnej 2010, 4: 174-80.

10. Broniarczyk-Dyła G, Wawrzycka-Kaflik A, Urysiak I. Keloidy i blizny przerosłe. Post Dermatol Alergol 2006; 22: 234-8.

11. Mustoe TA, Cooter RD, Gold MH, Hobbs FD, Ramelet AA Shakespeare PG, Stella M, Téot L, Wood FM, Ziegler UE; International Advisory Panel on Scar Management. International Clinical Recommendations on Scar Management. Plast Reconstr Surg 2002; 110: 560-71.
12. Zurada JM, Kriegel D, Davis CD. Topical treatments for hypertrophic scars. J Am Acad Dermatol 2006; 55: 1024-31.

13. Roques C, Teot L. A critical analysis of measurements used to assess and manage scars. Int J Lower Extr Wounds 2007; 6: 249-53.

14. Jamrógiewicz M, Żebrowska M, Łukasiak J, Sznitowska M. Silikonowe preparaty do leczenia powierzchniowego blizn. Farm Pol 2010; 66: 437-42.

15. Hanasono MM, Lum J, Caroll LA, Mikulec AA, Koch RJ. The effect of silicone gel on basic fibroblast growth factor levels in fibroblast cell culture. Arch Facial Plast Surg 2004; 6: 88-93.

16. Chang CC, Kuo YF, Chiu HC, Lee JL, Wong TW, Jee SH. Hydration, not silicone, modulates the effects of keratinocytes on fibroblasts. J Surg Res 1995; 59: 705-11.

17. Chan KY, Lau CL, Adeeb SM, Somasundaram S, Nasir-Zahari M. A randomized, placebo-controlled, double-blind, prospective clinical trial of silicone gel in prevention of hypertrophic scar development in median sternotomy wound. Plast Reconstr Surg 2005; 116: 1013-20.

18. Berman B, Perez OA, Konda S, Kohut BE, Viera MH, Delgado $\mathrm{S}$, Zell D, Li Q. A review of the biologic effects, clinical efficacy, and safety of silicone elastomer sheeting for hypertropic and keliod scar treatment and managment. Dermatol Surg 2007; 33: 1291-303.

19. Macek P, Terek-Derszniak M, Lipińska A, Błaszkiewicz E, Król H, Głuszek S, Góźdź S. Pressotherapy of a postoperative scar with the application of non-sterile silicone dressings in a 56-year-old woman treated for breast cancer in the Holycross Cancer Centre in Kielce. Studia Medyczne 2015; 31: 281-5.

\section{Address for correspondence:}

Anna M. Lipińska MD, PhD

Institute of Physioterapy

Faculty of Medicine of Health Sciences

Jan Kochanowski University

al. IX Wieków Kielc, 25-317 Kielce, Poland

Phone: +48 609735008

E-mail: al.reha@wp.pl 